\title{
PERSEPSI MAHASISWA DALAM MEMVALIDASI BUKTI MATEMATIS
}

\author{
Christi Matitaputty \\ Program Studi Pendidikan Matematika, Fakultas Keguruan dan Ilmu Pendidikan, Universitas Pattimura \\ Jalan Ir. Putuhena, Kampus Unpatti, Poka, Ambon, Indonesia \\ Program Studi Pendidikan Matematika, Pascasarjana, Universitas Negeri Malang \\ Jalan Semarang No.5, Sumbersari, Kec. Lowokwaru, Kota Malang, Jawa Timur, Indonesia \\ Submitted: September 3, 2020 \\ e-mail: chmatitaputty@gmail.com; \\ Revised: September 23, $2020 \quad$ Accepted: September 28, 2020 \\ corresponding author*
}

\begin{abstract}
Abstrak
Pentingnya menentukan persepsi mahasiswa dalam pembuktian matematis merupakan sebuah langkah awal dalam membantu siswa mengatasi kesulitan menyusun bukti matematis. Penelitian ini bertujuan mendeskripsikan persepsi mahasiswa dalam memvalidasi bukti matematis. Persepsi mahasiswa ini diperhatikan berdasarkan jawaban yang diberikan terhadap pembuktian sebuah teorema. Penelitian ini adalah penelitian kualitatif. Subjek dalam penelitian ini adalah dua orang mahasiwa semester 2 program studi pendidikan matematika Universitas Negeri Malang. Subjek penelitian dipilih secara purposif dengan pertimbangan sebagai berikut: mahasiswa memiliki jawaban yang menarik dan keterampilan komunikasi yang baik sehingga peneliti dapat mengeksplorasi persepsi mahasiswa dalam menulis bukti matematis. Data dikumpulkan dengan menggunakan instrument soal dan kemudian dianalisis hasil pekerjaan menyelesaiakan masalah serta dilakukan wawancara mendalam. Hasil penelitian menunjukan bahwa mahasiswa memiliki persepsi bahwa dengan memberikan beberapa contoh maka bukti disebut valid, satu contoh penyangkal dapat meverifiakasi pernyataan menjadi tidak valid dan dengan menggunakan bukti formal sebuah pernyataan dapat dibuktikan valid. Dengan demikian dosen seharusnya lebih banyak memberikan bimbigan, latihan dan mendorong mahasiswa untuk mengerjakan pembuktian matematis sehingga mahasiswa nantinya dapat membuat pembuktian yang valid
\end{abstract}

Kata Kunci: persepsi, validasi bukti matematis

\begin{abstract}
This study aims to describe the perceptions of prospective students in the first year in validating mathematical proof. This student's perception is discussed based on the answers given to the proof of a theorem. This research is a qualitative research. The subjects in this study were three students from the second semester mathematics education study program at a university in East Java. Research subjects were chosen deliberately with the following considerations: prospective teacher students who use examples in making mathematical proof and good communication skills make research can facilitate students' perceptions in writing mathematical proof. The results showed that students had perceptions about who gave several examples so that the proof was called valid, one example of denying it could prove it was invalid and using formal proof that proved it could be proven valid
\end{abstract}

Keywords: perception, validation mathematical proof

\section{Pendahuluan}

Kemampuan untuk menyusun bukti dalam matematika adalah keterampilan yang penting untuk setiap matematikawan. Kemampuan ini sering menjadi tujuan utama pembelajaran matematika tingkat lanjut. Namun, kenyataanya kegagalan dalam menyusun bukti matematis merupakan suatu hal umum yang sering dialami oleh mahasiswa dalam melalakukan pembuktian matematika tingkat lanjut. Sejumlah penelitian menunjukkan bahwa mahasiswa memiliki kesulitan dalam menulis dan menyusun bukti matematis oleh karena mereka tidak memiliki pengetahuan yang cukup tentang struktur bukti matematika (Almeida, 2000; Moore, 1994; Stylianides, 2007; Stylianides et al., 2004; Weber, 2001). Ada berapa sumber utama kesulitan yang dialami oleh mahasiswa universitas dalam pengalaman pendidikan matematika dalam membangun bukti diantaranya mahasiswa sulit memahami konsep, bahasa dan notasi matematika

Copyright (C) Authors. This is an open access article distributed under the Attribution-NonCommercialShareAlike 4.0 International (CC BY-NC-SA 4.0), which permits unrestricted use, distribution, and reproduction in any medium, provided the original work is properly cited. 
serta memulai sebuah bukti. Persepsi mahasiswa tentang matematika dan bukti sangat mempengaruhi proses pembuktian yang dilakukan (Moore, 1994).

Dari berbagai masalah diatas, banyak peneliti telah mencoba memberikan solusi agar kesalahan dapat diminimalisir. Pembuktian matematis dapat dilakukan dengan melakukan format dua kolom untuk membangun ide-ide dan bukti sehingga dapat mengakomodir proses pembuktian sehingga para guru diharapkan menunjukkan dan memperhatikan kesalahan proses pembuktian (Herbst, 2002). Selain itu Hazzan dan Zazkis (Hazzan \& Zazkis, 2003) menggunakan strategi mimikri bukti dengan bantuan computer yang bertujuan membantu mahasiswa mengurai bukti yang kompleks yang dapat dimanipulasi dengan bantuan komputer. Strategi ini diawali dengan diskusi tentang kesulitan mahasiswa dengan bukti matematika dan memperkenalkan ide mimikri bukti dengan contoh numerik. Dengan demikian mahasiswa memiliki banyak pengalaman dalam menyusun bukti matematis.

Bukti dan pembuktian merupakan suatu aktifitas yang penting bagi matematikawan dan pendidik matematika. Dengan demikian setiap mahasiswa matematika seharusnya mampu memahami dan membangun bukti matematika. Karena mereka akan mendidik selanjutnya generasi, ini menjadi sangat penting bagi seorang mahasiswa (Basturk, 2010). Penelitian-penelitian sebelumnya lebih berfokus pada pemahaman bukti matematika tingkat tinggi pada pembelajaran aljabar, analisis dan geometri. Namun kenyataannya menyusun bukti matematis masih menjadi masalah yang dialami oleh mahasiswa ditahun pertama perguruan tinggi. Hal ini sesuai dengan pengamatan Ball, dkk (Ball et al., 2003) bahwa pengajaran matematika dasar di banyak negara berfokus pada konsep aritmatika dari perhitungan, dan algoritma. Dengan demikian keadaan ini membuat mahasiswa mengalami adanya perubahan dalam proses berpikir akibat transisi matematika sekolah ke pembuktian formal dalam matematika murni perguruan tinggi. Dalam penelitian ini peneliti mencoba untuk menghadirkan masalah menyusun bukti matematis dari salah satu teorema yang berlaku pada bilangan bulat.

Masalah yang diberikan sangat sederhana dan tidak membutuhkan proses pembuktian yang kompleks karena hanya melibatkan konsep bilangan ganjil dan bilangan genap akan tetapi peneliti mengamati bahwa ada kesalahan yang terjadi ketika mahasiswa melakukan proses pembuktian. Padahal mahasiswa sudah diajarkan bagaimana menyusun bukti matematis dengan berbagai strategi pembuktian namun mahasiswa masih memilih membuktikan dengan menggunakan contoh-contoh dan meyakini bahwa contoh-contoh tersebut adalah bukti yang valid.

Berdasarkan observasi, peneliti menemukan bahwa masih banyak mahasiswa yang memiliki masalah ketika terlibat dalam penyusunan bukti matematis. Peneliti memberikan dua masalah. Soal pertama, apakah kuadrat suatu bilangan yang dikurangi satu akan bernilai genap jika bilangan tersebut adalah bilangan ganjil? Jika benar, apa yang saudara lakukan? Soal kedua, apakah jika jumlah dari dua bilangan bernilai ganjil maka salah satu bilangan tersebut adalah bilangan ganjil. Jika benar, apa yang saudara lakukan? Hal ini ditunjukan dari presentase mahasiswa yang menjawab benar untuk pertanyaan yang diberikan peneliti. Hasilnya menunjukan bahwa sebanyak $16 \%$ mahasiswa menjawab benar dalam pertanyaan pertama dan kedua.

Berdasarkan pengamatan ini maka peneliti menemukan bahwa mahasiswa mengalami kesulitan jika dihadapkan dengan masalah pembuktian. Peneliti percaya bahwa masih banyak mahasiswa yang mengalami kesalahan dalam menyelesaikan masalah pembuktian. Ketika mahasiswa mengalami kegagalan dalam menyusun bukti matematis maka ada kemungkinan bahwa mereka tidak memiliki pemahaman konseptual yang mendalam. Jika mereka tidak memiliki pemahaman yang kuat, tentu menjadi masalah ketika mereka mulai mengajar sebagai guru matematika, baik di sekolah dasar, menengah dan menengah. pentingnya membuktikan dalam pendidikan matematika tidak bisa diabaikan. Oleh karena itu, langkah pertama dalam membantu siswa mengatasi kesulitan tersebut adalah menentukan persepsi mereka tentang pembuktian. Penting bagi peneliti untuk melakukan penelitian terkait dengan persepsi mahasiswa dalam menyusun bukti matematis (Almeida, 2000; Anapa, 2010; Aylar, 2014; Basturk, 2010; Lesseig et al., 2019; Studies, 2016)

Tujuan dari penelitian ini adalah untuk meneskripsikan bagaimana persepsi mahasiswa dalam memvalidasi bukti matematis. Harapannya adalah bahwa penelitian ini dapat digunakan sebagai refleksi, untuk mempersiapkan mahasiswa untuk pemahaman mendalam mereka tentang proses menyusun bukti matematis. Mahasiswa kemudian menjadi guru matematika di sekolah, tentu saja, harus memiliki pemahaman tentang bukti matematis yang mendalam sehingga mereka tidak mengalami banyak gangguan dalam 
membangun konsep matematika. Oleh karena itu, pertanyaan penelitian ini adalah "bagaimana persepsi mahasiswa dalam memvalidasi bukti matematis.

\section{Metode Penelitian}

Penelitian ini melibatkan 37 mahasiswa dari program Pendidikan Matematika semester kedua, tahun akademik 2019/2020 Universitas Negeri Malang. Semua mahasiswa diberikan dua masalah untuk melihat kemampuan mahasiswa dalam meyusun bukti matematis. Soal yang diberiikan tidak langsung menuliskan perintah untuk membuktikan namun memberikan arahan bagaimana mereka harus membuktikan sebuah pernyataan atau teorema yang diberikan. Diharapkan dari kedua soal yang diberikan mahasiswa dapat membuktikan pernyataan atau teorema yang diberikan dengan menggunakan metode pembuktian.

Peneliti memilih subjek dengan mempertimbangkan keterampilan komunikasi dan jawaban dengan beberapa tipe persepsi (Moralı et al., 2006) yaitu mahasiswa tipe A menerima dan bekerja dengan bukti formal dan menolak bukti informal. Tipe B lebih memilih menggunakan bukti informal untuk menuju bukti formal; mahasiswa tipe $\mathrm{C}$ sebagaian besar lebih menyukai bukti informal ketika dibandingkan dengan bukti formal dan mahasiswa tipe D lebih suka bukti formal tetapi mereka tidak bisa mencapai kesimpulan karena menyalahgunakan bahasa matematika dan symbol. Berdasarkan kriteria ini, peneliti memperoleh dua subjek penelitian. Dari dua mahasiswa tersebut, peneliti melakukan wawancara satu per satu untuk mengeksplorasi secara mendalam informasi terkait pekerjaan mereka dan untuk mengetahui bagaimana persepsi mahasiswa dalam memvalidasi bukti matematis. Pada akhirnya, peneliti dapat mengetahui persepsi mahasiswa tentang bukti matematis.

\section{Hasil dan Pembahasan}

Ketika peneliti mengajukan pertanyaan: (1) apakah kuadrat suatu bilangan yang dikurangi satu akan bernilai genap jika bilangan tersebut adalah bilangan ganjil? Jika benar, apa yang saudara lakukan? (2) apakah jika jumlah dari dua bilangan bernilai ganjil maka salah satu bilangan tersebut adalah bilangan ganjil. Jika benar, apa yang saudara lakukan? Maka ada $84 \%$ mahasiswa salah menjawab. Di antara kesalahan-kesalahan ini, sebagian besar mahasiswa menjawab dengan menggunakan contoh-contoh untuk menyusun bukti dari pernyataan yang diberikan.

Mahasiswa tahun pertama ini sudah menempuh mata kuliah landasan matematika yang mana sudah diberikan cara dan metode menyusun bukti matematis bahkan dalam pembelajaran pun mereka sudah diperingati untuk tidak menggunakan contoh dalam menyusun bukti matematis. Namun, kenyataannya peneliti menemukan masih banyak yang menggunakan contoh-contoh dan meyakini contoh-contoh ini sebagai bukti yang valid. Mahasiswa memahami pernyataan yang diberikan itu benar dan berlaku untuk untuk beberapa bilangan genap atau ganjil yang dipilih.

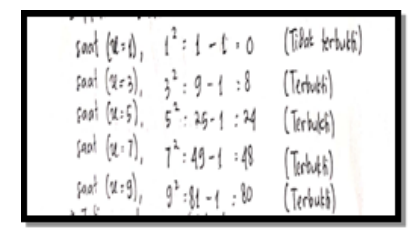

a

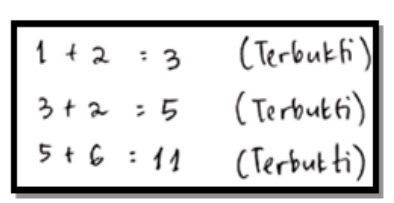

b
Gambar 1. Pekerjaan Subjek AD soal no 1(a) soal no 2 (b)
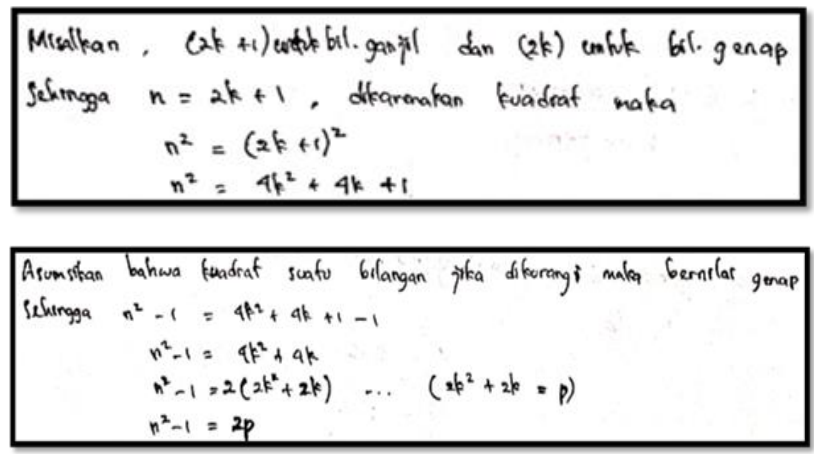

Gambar 2. Pekerjaan Subjek EP

Pada Gambar 1, subjek AD memberikan gambaran bahwa bukti adalah sebuah sarana untuk membangun kebenaran matematika dan menunjukan hasilnya benar tanpa keraguan dalam pandangan mereka. Dengan memisalkan suatu bilangan ganjil dan menggunakan beberapa contoh bilangan maka mahasiswa tersebut merasa bahwa proses pembuktiannya sudah benar. Selain itu, mahasiswa juga memberikan beberapa contoh sehingga memberi keyakinan bahwa bukti yang ditulis sudah cukup dan benar. Begitupula untuk masalah kedua, subjek AD masih menggunakan beberapa contoh untuk memverifikasi pernyataan yang diberikan. Sementara di gambar 2 mahasiswa memiliki persepsi yang lain, subjek EP mampu menulisakan buki secara formal dengan memisalkan atau menuliskan apa yang diketahui menuju ke kesimpulan yang akan dibuat. Subjek EP menuliskan defisini bilangan ganjil dan genap kemudian berangkat dari definisi menuju apa yang 
akan dibuktikan yaitu kuadarat suatu bilangan ganjil yang dikurangi 1 menghasilkan bilangan genap. Dari interpretasi jawaban yang diperoleh maka peneliti maka peneliti melakukan wancara lebih lanjut untuk menelusuri apa yang menyebabkan mahasiswa tersebut memberikan argument seperti itu.

Penggalan wawancara ditunjukan dalam wawancara 1

\section{Dialog 1}

Peneliti : Mengapa anda menggunakan contoh untuk membuktikan pernyataan tersebut benar?

Subjek : Y Yang ada dalam pikiran saya adalah $\mathrm{AD} \quad$ menggunakan contoh bu dan saya rasa dengan contoh bilanganbilangan yang saya tulis itu sudah cukup untuk membuktikan bahwa pernyataan tersebut benar.

Peneliti : Apa yang anda ketahui tentang pembuktian?

Subjek : Sesuatu yang harus dibuktikan AD kebenarannya.

Peneliti : Apa yang kamu maksudkan dengan sesuatu?

Subjek : Maksudnya,pernyataan bu.

AD

Peneliti : Apa maksud kamu menuliskan saat $\mathrm{x}=1,1^{2}=1-1=0$ (tidak terbukti)?

Subjek : Artinya saat saya mensubtitusi nilai

$\mathrm{AD} \quad 1$ yang dikuadaratkan dan dikurangi 1 itu bukan bilangan genap bu, tapi nol.

Peneliti : Berarti kamu menganggap pernyataan yang diberikan ini salah?

Subjek : Iya bu, salah saat dipilih $\mathrm{x}=1$ tapi AD benar untuk yang lain.

Peneliti : Mengapa disoal no 2 anda menjawab seperti itu?

Subjek : Karena saya piker dengan AD memberikan beberapa contohcontoh bilangan yang sesuai dengan pernyataan maka itu sudah cukup dan benar bu.

Dari wawancara dalam Dialog 1, subjek memahami bahwa meyakini bahwa contoh-contoh tersebut berlaku secara umum dan diyakini benar dapat membuktikan pernyataan dimaksud. Selanjutnya subjek memahami pembuktian sebatas pernyataan yang harus dibuktikan dan belum didukung alasan yang jelas. Masalah pembuktian jarang dikerjakan sehingga mahasiswa tidak punya pengetahuan yang luas tentang pembuktian. Dalam menyelesaikan soal no 2 subjek masih tetap berfokus pada menggunakan contoh-contoh dan diyakini sebagai bukti yang valid. Hal ini menunjukan bahwa mahasiswa belum memahami bagaimana memulai sebuah bukti dan menyatakan bukti itu valid secara formal. Hal ini sejalan denga temuan (Aylar, 2014) bahwa mahasiswa lebih suka memverivikasi bukti denan contoh contoh karena mereka mengalami kesulitan dalam memahami dan menerapkan ekspresi aljabar. Temuan penelitian ini mendukung penelitian sebelumnya yang menemukan bahwa banyak mahasiswa yang salah dalam menyusun bukti matematis dan meyakini contoh-contoh sebagai bukti yang valid (Tuba et al., 2014) selain itu pembuktian dengan memberikan contoh penyanggah juga membuat pernyataan menjadi semakin logis (Aylar, 2014). Dengan demikian untuk memahami dan menulis bukti matematis perlu dipahami definisi, sifat-sifat dan aturan-aturan dasar yang berlaku pada operasi bilangan sehingga dalam proses pembuktian dapat berjalan dengan baik (Velleman, 2006).

Peneliti melakukan wawancara dengan Subjek EP mengenai proses pembuktian yang dilakukan. Kutipan wawancara seperti yang ditunjukkan dalam Dialog 2.

\section{Dialog 1}

Peneliti : Mengapa kamu menuliskan seperti ini? Subjek : Disini saya menuliskan apa yang ada EP dipikiran saya, saya mencoba melakukan pembuktian langsung. Ketika saya memisalkan bilangan ganjil $2 \mathrm{k}+1$ dan bilangan genap itu $2 \mathrm{k}$. bilangan berapapun yang dikalikan 2 akan selalu genap dan ketika ditambah 1 akan menghasilkan bilangan ganjil. Karena dimnta $n$ kuadarat maka kedua ruas dikuadaratkan. Kemudian saya asumsikan kuadrat suatu bilangan yang dikurangi satu akan menghasilkan bilangan genap.selanjutnya $\mathrm{n}$ kuadarat dikurangi 1 akan sama sengan $4 \mathrm{k}^{2}+$ $4 \mathrm{k}+1$ sehingga diperoleh $\mathrm{n}^{2}-1=$ 2p. Jadi kuadrat suatu bilangan yang dikurangi satu akan menghasilkan bilangan genap.

Peneliti : Mengapa kamu menjawab seperti ini?

Subjek : Saya menjawab seperti itu, karena EP dengan pembuktian itu akan terlihat secara logis hasil dari pernyataan tersebut.

Peneliti : Apa yang kamu ketahui tentang pembuktian?

Subjek : Pembuktian itu kan, untuk menyatakan EP atau mencari pertanyaan/dugaan mengenai suatu hal yang masih patut dipertanyakan bu. So, dengan pembuktian kita bisa menyatakan sesuatu pernyataan tersebut bernilai salah atau benar.

Peneliti : Apa maksud kata pernyataan/dugaan, apakah pernyataan itu sama dengan dugaan? Mengapa 


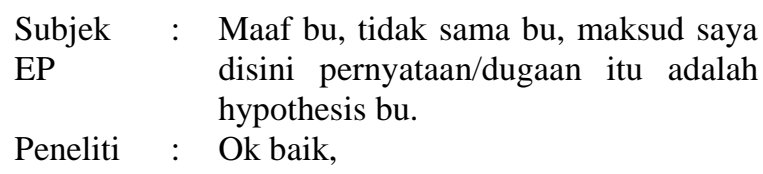

Subjek EP memiliki persepsi yang berbeda dengan subjek DA. Jawaban subjek EP menyatakan bahwa bukti yang diberikan mengarah pada verifikasi pernyataan yang menjelaskan mengapa pernyataan itu benar dan dapat diterima dengan logis atau masuk akal. Hal ini sesuai dengan pernyataan (Almeida, 2000) bahwa bukti matematis dari sebuah pernyataan yang pada umumnya dipahami memiliki empat fungsi utama: (i) verifikasi pernyataan, (ii) penjelasan pernyataan, (iii) komunikasi kepada orang lain, (iv) sistematisasi dari pernyataan ke dalam sistem deduktif. Subjel EP sudah memahami soal dan memulai dengan membuat pemisalan atas bilangan ganjil dan bilangan genap. Proses membuktikan berkaitan erat dengan pengetahuan awal yang dimiliki mahasiswa saat mahasiswa punya banyak pengalaman dalam membuktikan pernyataan matematis maka mahasiswa akan dengan mudah menggunakan bukti formal sebagai bukti valid. Selain itu, hasil penelitian (Tuba et al., 2014) menyatakan bahwa terdapat beberapa mahasiswa yang lebih menyukai cara formal dalam proses pembuktian. Bukti matematika memberikan jaminan untuk pengetahuan matematika dan merupakan kegiatan penting dalam melakukan dan memahami matematika. Ketika proses pembuktian teorema dianalisis, ditentukan bahwa mahasiswa yang diketik lebih suka cara formal saat pembuktian.

Dengan demikian persepsi mahasiswa terhadap bukti matematis ini memberikan gambaran bahwa siswa kurang memiliki banyak pengalaman belajar dalam menyelesaikan soal-soal pembuktian, sehingga untuk meningkatkan persepsi mahasiswa dosen secara rutin dapat memberikan banyak latihan dan bimbingan bagi mahasiswa dalam mengerjakan soal-soal pembuktian. Penelitian ini memiliki keterbatasan dengan hanya memotret persepsi dari dua orang mahasiswa dan tidak dapat di generalisasi sehingga diperlukan penelitian lanjutan dengan memperhatikan jumlah subjek penelitian maupun kemampuan matematis lainnya.

\section{Kesimpulan}

Berdasarkan pembahasan maka dapat disimpulkan persepsi mahasiswa dalam menyusun bukti matematis yaitu mahasiswa memiliki persepsi dalam memverivikasi bukti matematis dengan contoh contoh karena mereka mengalami kesulitan dalam memahami dan menerapkan ekspresi aljabar. Selain itu pembuktian dengan memberikan contoh penyanggah juga membuat pernyataan menjadi semakin logis. Persepsi mahasiswa dalam membangun bukti matematis diyakini dengan memahami notasi aljabar sebagai buktinya dan memiliki kecenduruang untuk melakukan cara formal dalam pembuktian matematis.

\section{Daftar Pustaka}

Almeida, D. (2000). A survey of mathematics undergraduates' interaction with proof: some implications for mathematics education. 31(6), 869-890.

Anapa, P. Õ. (2010). Investigation of undergraduate students ' perceptions of mathematical proof. 2 , 2700-2706. https://doi.org/10.1016/j.sbspro.2010.03.399

Aylar, E. (2014). A Study on the Forms of Perception of 7th Grade Students towards the Concept of Proof. Journal of Education and Future, 5, 39-56.

Ball, D. L., Hoyles, C., Jahnke, H. N., \& MovshovitzHadar, N. (2003). The teaching of proof. III. http://arxiv.org/abs/math/0305021

Basturk, S. (2010). First-year secondary school mathematics students' conceptions of. 36(3), 283-298. https://doi.org/10.1080/03055690903424964

Hazzan, O., \& Zazkis, R. (2003). Mimicry of proofs with computers: The case of Linear Algebra. International Journal of Mathematical Education in Science and Technology, 34(3), 385-402. https://doi.org/10.1080/0020739031000108628

Herbst, P. G. (2002). Engaging students in proving: A double bind on the teacher. Journal for Research in Mathematics Education, 33(3), 176-203. https://doi.org/10.2307/749724

Lesseig, K., Hine, G., \& Na, G. S. (2019). Perceptions on proof and the teaching of proof: A comparison across preservice secondary teachers in Australia, USA and Korea. https://doi.org/10.1007/s13394-019-00260-7

Moore, R. C. (1994). Making the transition to formal proof*. 249-266.

Moralı, S., Ugurel, I., Türnüklü, E., \& Yeşildere, S. (2006). The views of the mathematics teachers on proving. Kastamonu Education Journal, 14(1), 147-160.

Studies, I. E. (2016). Preservice Mathematics Teachers' Metaphorical Perceptions towards Proof and Proving. 9(7), 88-97. https://doi.org/10.5539/ies.v9n7p88

Stylianides, A. J. (2007). Proof and proving in school mathematics. Journal for Research in Mathematics Education, 38(3), 289-321.

Stylianides, A. J., Stylianides, G. J., \& Philippou, G. N. (2004). Undergraduate students' understanding 
of the contraposition equivalence rule in symbolic and verbal contexts. 133-162.

Tuba, F., Övez, D., \& Özdemir, E. (2014). The Investigation of Prospective Mathematics Teachers' Proof Writing Skills and Proof SelfEfficacy. Procedia - Social and Behavioral Sciences, 116(2010), 4075-4079. https://doi.org/10.1016/j.sbspro.2014.01.893
Velleman, D. (2006). How to Prove It: A structed Approach (Vol. 60, Issue 4, p. 1329). https://doi.org/10.2307/2275901

Weber, K. (2001). Student difficulty in constructing proofs: The need for strategic knowledge. Educational Studies in Mathematics, 48(1), 101119. https://doi.org/10.1023/A:1015535614355. 